\title{
Prioritas Penentuan Peningkatan Kualitas Lingkungan Permukiman Kumuh yang Berkelanjutan
}

\author{
Zenal Mutaqin $^{1 *}$, Citra Persada ${ }^{2}$, Erdi Suroso ${ }^{3}$ \\ ${ }^{1}$ Program Studi Magister Ilmu Lingkungan, Pascasarjana Universitas Lampung, Bandar Lampung 35145 \\ ${ }^{2}$ Program Studi Teknik Sipil, Fakultas Teknik, Universitas Lampung, Bandar Lampung 35145 \\ 3 Studi Teknologi Hasil Pertanian, Fakultas Pertanian, Universitas Lampung, Bandar Lampung 35145 \\ *Penulis korespondensi, e-mail: zenalmutaqin505@gmail.com
}

\begin{abstract}
Abstrak
Peningkatan kualitas permukiman di berbagai spot Kota Palembang diharapkan terus berkelanjutan seiring banyaknya lokasi kumuh dan terbatasnya dana alokasi yang perlu penanganan. Tujuan dari penelitian ini menentukan kegiatan dan lokasi skala prioritas berdasarkan 3 pilar pembangunan berkelanjutan yang dapat mengurangi tingkat kekumuhan yaitu fisik lingkungan, sosial dan ekonomi dengan melibatkan pemangku kepentingan. Penelitian ini akan memberikan informasi bagi pemerintah daerah untuk menentukan kegiatan prioritas dan lokasi untuk perbaikan pemukiman dengan menggunakan Analytical Hierarchy Process (AHP). Hasil penelitian menyebutkan untuk peningkatan kualitas permukiman daerah 29 Ilir adalah faktor pembangunan fisik lingkungan dengan tingkat kepentingan 46,7\%, faktor kegiatan sosial dengan tingkat kepentingan 31,2\% dan faktor peningkatan ekonomi dengan tingkat kepentingan 22,1\%. Masing-masing kegiatan faktor yang menjadi prioritas adalah mengelola sampah rumah tangga sebesar $100 \%$, sarana persampahan sebesar $93,5 \%$, kegiatan gotong royong sebesar $83,6 \%$, drainase sebesar $66,2 \%$, sanitasi sebesar $66,1 \%$, pinjaman modal usaha sebesar $63 \%$, pelatihan dan kewirausahaan sebesar $61 \%$ serta santunan bagi masyarakat miskin sebesar 57,9\%. Kegiatan peningkatan kualitas permukiman dilaksanakan di lokasi prioritas dimana 5 lokasi yang terpilih memiliki kualitas lingkungan yang rendah.
\end{abstract}

Kata Kunci: permukiman kumuh, peningkatan kualitas pengelolaan sampah, sarana sampah, gotong royong, 5 lokasi, AHP

\begin{abstract}
The enhancement of environmental quality for urban settlement in Palembang is expected to be sustainable due to the increase number of slum areas and the limited funding allocation for the infrastructure establishment. This study aimed to determine priority scale of activities and locations according to three pillars of sustainable development which can alleviate slum areas i.e. physical environment, social and economic aspects by involving all stakeholders. This research will provide information for the local government to determine priority activities and locations for settlement improvement by using Analytical Hierarchy Process (AHP). The study revealed that the main factor to improve the environmental quality for settlement in 29 Ilir sub-district was the infrastructure development with urgency level reaching 46.7\%. Meanwhile, the urgency level of social activity factor was approximately $31.2 \%$ followed by the economic development factor which was the lowest level by $22.1 \%$. However, the highest priority level from those activity factors was household waste management by $100 \%$,
\end{abstract}


while other priority activities that should be done consecutively were waste infrastructure (93.5\%), community service activities (83,6\%), environmental drainage (66.2\%), sanitation (66.1\%), business capital loans (63\%), training and entrepreneurship (61\%), and compensation for the poor (57,9\%). The aforementioned activities were conducted in priority locations in which environmental quality was relatively poor.

Keywords: slum area, quality improvement, household waste management, waste infrastructure, community service activities, 5 location, $A H P$

\section{Pendahuluan}

Permukiman kumuh merupakan gambaran kawasan perumahan tidak beraturan, kurangnya pelayanan infrastruktur dengan jumlah populasi yang dilayani, sehingga berdampak pada kondisi kualitas fisik dan lingkungan perumahan yang tidak memenuhi persyaratan keselamatan, kesehatan, kenyamanan, serta kemudahan (Puslitbang,2011). Pada tahun 2030, tiga miliar penduduk kota diperkirakan hidup di perkampungan kumuh, padat penduduk, padat bangunan, dan berkualitas lingkungan buruk (Joga, 2013). Berbagai lembaga yang menangani permukiman kumuh salah satunya di Kota Palembang telah melakukan perbaikan kualitas lingkungan permukiman dengan tipologi kumuh seiring dengan keluarnya penetapan lokasi permukiman kumuh seperti daerah 29 Ilir kecamatan Ilir barat 2 (Surat Keputusan Walikota Palembang Nomor 488 Tahun 2014 Tentang Penetapan Lokasi Kawasan Permukiman). Penanganan perbaikan permukiman kumuh di daerah 29 Ilir berdasarkan selain dari faktor infrastruktur permukiman, pembangunan rumah tinggal serta peningkatan sosial dan ekonomi (Peraturan Menteri Pekerjaan Umum dan Perumahan Rakyat No.2/PRT/M/2016 Tentang Peningkatan Kualitas Terhadap Perumahan Kumuh dan Permukiman Kumuh) juga pengembangan pembangunan berkelanjutan berdasarkan 3 aspek keberlanjutan lingkungan hidup, keberlanjutan secara ekonomi dan keberlanjutan secara sosial dan politik (Syahri, 2013).

Peningkatan kualitas terhadap permukiman yang memiliki tipologi kumuh di Kota Palembang masih terkonsentrasi pada pembangunan fisik seperti perbaikan jalan, saluran, penyediaan air bersih serta perbaikan rumah. Namun aspek terhadap kondisi sosial, ekonomi terutama komitmen masyarakat dalam peranannya menjaga kualitas lingkungan permukiman belum terlihat. Selain itu belum ada peran stakeholder (pemangku kepentingan) yang melibatkan akademisi, swasta dan pemerintah serta masyarakat lainnya untuk menilai dalam menentukan prioritas peningkatan kualitas permukiman di Kota Palembang. Permukiman kumuh di Kota Palembang tersebar di 59 spot (titik), dengan luas sekitar 2.473 Ha, salah satunya daerah yang memiliki tipologi kumuh berat yaitu daerah 29 Ilir dengan luas lahan 16,73 ha, jumlah penduduk 8.928 jiwa dan merupakan bagian dari wilayah administrasi Kecamatan Ilir Barat 2 serta berdekatan ditepian sungai musi, pusat pemerintahan, ekonomi dan pariwisata di Kota Palembang.

Permasalahan yang dialami daerah 29 ilir saat ini, terkait kondisi kualitas fisik drainase perumahan yang saling berhubungan dengan saluran utama dan menuju ke sungai Musi belum sepenuhnya terkoneksi dengan baik, selain itu tumpukkan sampah masih terlihat di sekitar permukiman terutama badan saluran. Masalah lainnya seperti kebutuhan air bersih di lokasi penelitian sebagian belum terdistribusi atau terlayani dengan baik, begitu juga kondisi sistem sanitasi rumah tangga masih tercampur dengan saluran drainase serta bangunan tempat tinggal masih ada yang tidak layak untuk ditempati, sebagian jalan lingkungan di lokasi penelitian dengan kondisi perkerasan kurang baik, serta kondisi sosial, budaya dan ekonomi masih relatif rendah.

Ketidakoptimalan perbaikan permukiman kumuh di Kota Palembang khususnya daerah 29 Ilir karena keterbatasan alokasi anggaran menjadi kendala dan banyaknya spot-spot daerah kumuh yang perlu perbaikan. Pada akhirnya penataan dan perbaikan kualitas lingkungan permukiman kumuh di Kota Palembang tidak dapat seluruhnya dilaksanakan secara serentak. Diperlukan sebuah sistem dalam pengambilan keputusan yang menentukan kegiatan dan lokasi prioritas terhadap pengembangan dari 3 pilar pembangunan yaitu fisik lingkungan, sosial, ekonomi serta komitmen masyarakat memelihara lingkungan 
permukiman dengan melibatkan peran penilaian stakeholder. Maka dari itu diperlukan studi penelitian terkait permasalahan penentuan peningkatan kualitas permukiman yang berada di daerah 29 Ilir dengan menggunakan metode analisis hierarki proses (AHP). Penelitian tersebut diharapkan dapat memberikan kontribusi kepada pemerintah dalam menentukan skala prioritas kegiatan dan lokasi untuk dilaksakanan sesuai dengan aspirasi masyarakat terkait kebutuhan perbaikan kualitas permukiman yang tersebar di Kota Palembang.

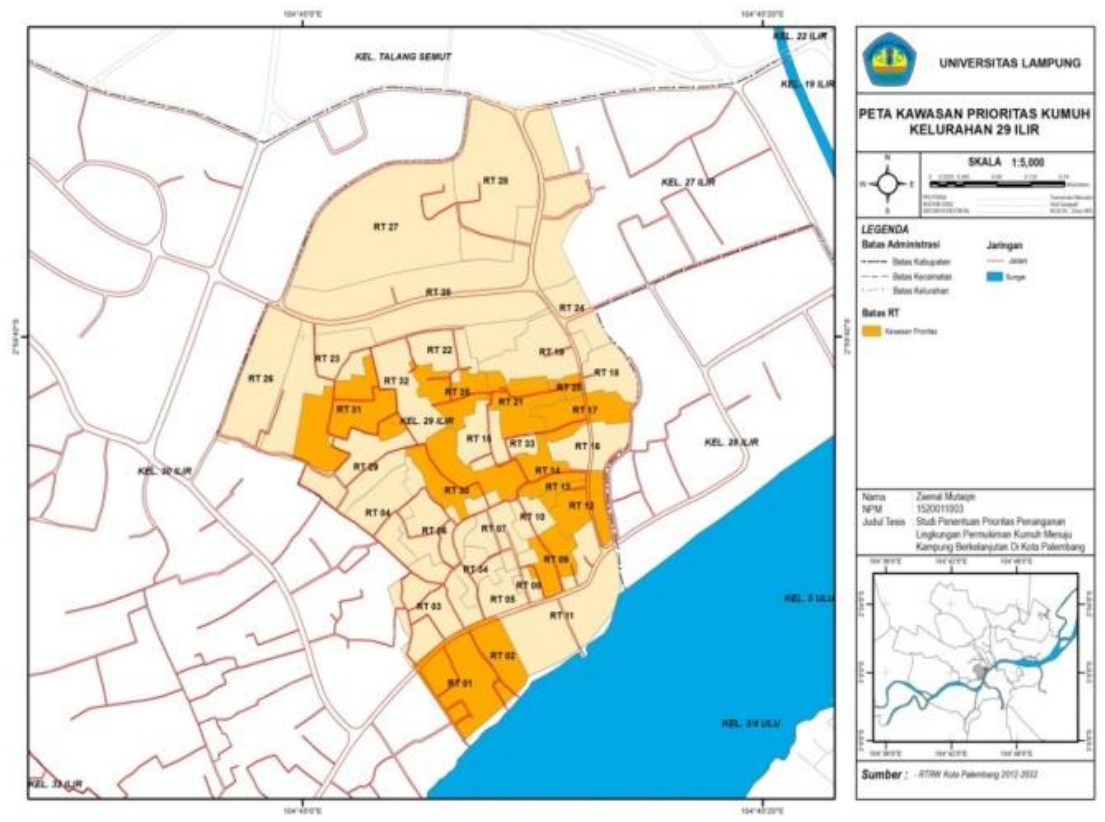

Gambar 1. Sebaran lokasi kumuh daerah 29 Ilir

\section{Metode Penelitian}

Penelitian dilaksanakan di daerah 29 ilir Kecamatan Ilir Barat 2 Kota Palembang. Daerah ini memiliki tipologi kumuh dengan luas lahan 16,73 ha telah ditetapkan berdasarkan Keputusan Walikota Palembang Nomor 488 Tahun 2014 Tentang Penetapan Lokasi Kawasan Permukiman Kumuh di Kota Palembang. Tujuan dari penelitian ini adalah menentukan kegiatan dan lokasi skala prioritas berdasarkan pengembangan dari 3 pilar pembangunan berkelanjutan yang dapat mengurangi tingkat kekumuhan yaitu faktor pembangunan fisik lingkungan, faktor peningkatan sosial dan ekonomi dengan melibatkan pemangku kepentingan. Manfaat penelitian ini diharapkan memberikan kemudahan bagi pemerintah dalam menentukan kegiatan perbaikan permukiman kumuh dan lokasi prioritas dengan menggunakan sistem metode AHP dan hasil akhirnya dapat digunakan sebagai dasar perencanaan. Proses pengumpulan data dilakukan melalui data kondisi dilapangan dengan cara observasi, kuesioner, wawancara serta dokumentasi dan berbagai data dokumen dari instansi atau lembaga yang menangani masalah perumahan dan permukiman melalui program peningkatan kualitas kawasan permukiman.

Penentuan responden menggunakan teknik Purposive Sampling, dimana responden dianggap sebagai orang yang mengetahui permasalahan permukiman Kota Palembang. Sumber responden terdiri dari 2 kelompok, pertama stakeholder 7 orang meliputi pemerintah, lembaga non pemerintah, pemerhati lingkungan hidup serta akademisi untuk menentukan prioritas kegiatan perbaikan kualitas permukiman di berbagai spot-spot daerah 29 Ilir Kota Palembang. Kedua 36 orang terdiri dari ketua rukun tetangga dan masyarakat lainnya untuk menentukan lokasi priortas berdasarkan kualitas lingkungan permukiman masingmasing lokasi. Variabel dalam penelitian ini berdasarkan pengembangan dari 3 pilar pembangunan berkelanjutan terdiri dari 15 sub-faktor kegiatan antara lain faktor fisik lingkungan terdiri dari kegiatan perbaikan atau pembangunan jalan, drainase, air minum, persampahan, sarana proteksi kebakaran, sanitasi 
lingkungan, perbaikan rumah dan ruang publik/RTH. Kedua faktor sosial terkait partisipasi masyarakat dalam memeliharan lingkungan permukiman melalui kegiatan penyediaan rth privat, membuat resapan biopori, kegiatan gotong royong dan kesediaan mengelola persampahan rumah tangga. Ketiga faktor ekonomi terdiri dari kegiatan pelatihan kewirausahaan, pinjaman modal usaha dan santunan bagi masyarakat miskin.

Teknik pengambilan keputusan menggunakan metode analisis hierarki proses (AHP) dengan bantuan program. Analisis tersebut merupakan salah satu sistem teknik pengambilan keputusan yang dapat dipahami, tidak kaku mudah disesuaikan untuk berbagai masalah (Atmanti, 2008). Proses analisis model ahp terdiri dari beberapa urutan hirarki dengan pertama kali menentukan tujuan utama, dilanjutkan dengan kriteria atau faktor, sub kriteria atau sub faktor dan kemungkinan adanya alternatif-alternatif pada tingkatan yang terakhir (Atmanti, 2008). Penilaian perbandingan berpasangan (pair-wise comparison) berdasarkan skala penilaian satu sampai dengan sembilan disertai adanya nilai tengah diantara nilai ganjil dengan menghasilkan nilai bobot faktor (weight Factor) dan nilai faktor evaluasi (evaluation factor), dimana nilai bobot alternatif yang tertinggi (weight score) maka nilai bobot tersebut merupakan prioritas (Khoirunnisa dkk, 2013)

Tabel 1. Nilai Skala Perbandingan Berpasangan

\begin{tabular}{l|l}
\hline $\begin{array}{l}\text { Tingkat } \\
\text { Kepentingan }\end{array}$ & Kriteria \\
\hline $\mathbf{1}$ & Sama-sama Penting \\
$\mathbf{3}$ & Sedikit Lebih Penting \\
$\mathbf{5}$ & Lebih Penting \\
$\mathbf{7}$ & Sangat Penting \\
$\mathbf{9}$ & Mutlak Sangat Penting \\
$\mathbf{2 , 4}, 6$ dan 8 & Nilai Tengah \\
\hline
\end{tabular}

Sumber: Saaty, 1990

Tahapan analisis dengan metode analisis hierarki proses (AHP) adalah sebagai berikut:

a. Menginput data faktor, sub faktor kegiatan dan alternatif lokasi kedalam struktur hierarki yang telah teridentifikasi yang berpengaruh terhadap rencana tujuan utama (goal).

b. Penilaian oleh masing-masing stakeholder melalui skala perbandingan berpasangan (pair-wise comparison) dalam menentukan prioritas antar faktor dan antar subfaktor kegiatan.

c. Penilaian dari tokoh masyarakat untuk menentukan lokasi alternatif berdasarkan penilaian kualitas lingkungan masing-masing lokasi.

d. Pengujian konsistensi responden dalam menentukan pilihan. Apabila nilai rasio konsistensi $\leq 10 \%$ (kurang dari o,10 \%) menunjukkan kekonsistenan para pengambil keputusan sehingga nilai bobot tersebut dapat direkomendasikan sebagai prioritas. Sebaliknya nila rasio konsistensi lebih besar dari o,10 \% maka perlu meninjau kembali terhadap nilai yang tidak termasuk kedalam kriteria yang diharapkan dengan melakukan penilaian ulang sampai nilai tersebut diterima.

\section{Hasil dan Pembahasan}

3.1. Prioritas Kepentingan Peningkatan Kualitas Permukiman Kumuh Berdasarkan 3 Pilar Pembangunan Berkelanjutan

Berdasarkan hasil penilaian stakeholder, nilai skala prioritas 3 pilar pembangunan untuk peningkatan kualitas permukiman kumuh di daerah 29 ilir, pertama faktor fisik lingkungan menghasilkan tingkat kepentingan sebesar 46,70 \%, kedua faktor sosial dalam bentuk peran serta dan komitmen masyarakat dalam memelihara lingkungan permukimannya dengan tingkat kepentingan sebesar 31,20 \%, ketiga faktor peningkatan ekonomi masyarakat dengan tingkat kepentingan sebesar 22,10 \%, dengan 
inconsistency responden sebesar $0,01(<0,1 / 10 \%)$, nilai tersebut menunjukkan adanya kekonsistenan dalam menentukan keputusan penilaiannya.

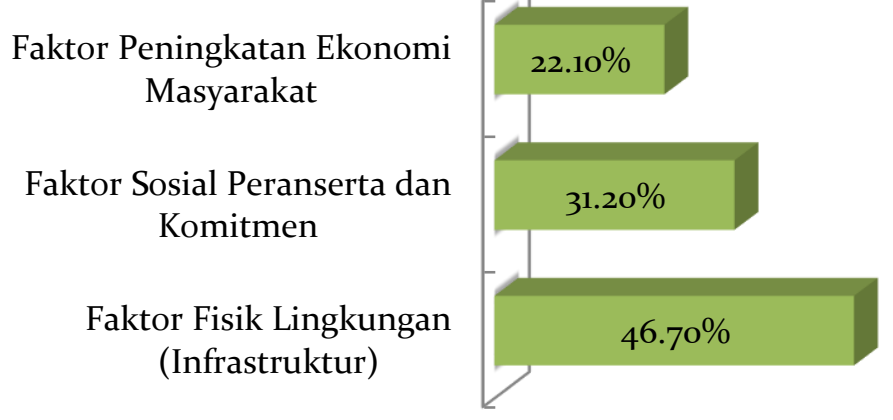

Gambar 2. Prioritas Faktor Peningkatan Kualitas Permukiman Kumuh

\subsubsection{Prioritas Sub-Faktor Fisik Lingkungan}

Sub faktor dari fisik lingkungan terdiri dari 8 kegiatan dengan menghasilkan nilai prioritas, secara rinci disajikan pada Gambar 3.

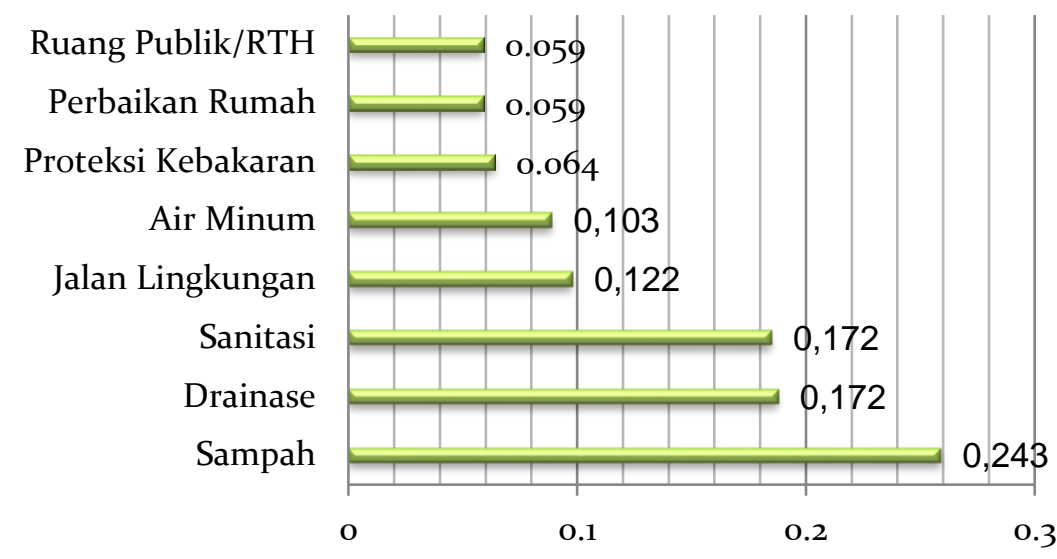

Gambar 3. Bobot Prioritas Berdasarkan sub-faktor Fisik Lingkungan

Hasil penilaian stakeholder pada gambar 4 tersebut diatas, menghasilkan beberapa penilaian. Ada 3 (tiga) sub faktor yang cukup tinggi nilainya adalah, prioritas pertama sampah dengan nilai bobot sebesar o, $243 \%$ atau $(24,3 \%)$, prioritas kedua drainase dengan nilai bobot sebesar $0,172 \%$ atau $(17,2 \%)$, dan prioritas ketiga sanitasi dengan nilai bobot sebesar $0,172 \%$ atau $(17,2 \%)$ dengan inconsistency responden sebesar o,03 $(<0,1 / 10 \%)$, nilai tersebut menunjukkan adanya kekonsistenan dalam menentukan keputusan penilaiannya.

\subsubsection{Prioritas Sub-Faktor Aspek Sosial}

Sub faktor aspek sosial dalam bentuk komitmen, melalui partisipasi masyarakat dalam memelihara lingkungan permukiman terdiri dari 4 kegiatan dengan menghasilkan nilai prioritas berdasarkan penilaian stakeholder menunjukkan kegiatan kesediaan masyarakat untuk mengelola sampah dengan nilai kepentingan sebesar $0,506 \%$ atau $(50,6 \%)$, prioritas kedua adalah kegiatan gotong royong dengan nilai kepentingan sebesar $0,263 \%$ atau (26,3\%). Sedangkan inconsistency responden $0,04(<0,1 / 10 \%)$, nilai tersebut menunjukkan adanya kekonsistenan responden dalam menentukan prioritas kegiatan terhadap sub faktor. Gambaran umum hasil penilaian disajikan pada Gambar 4. 


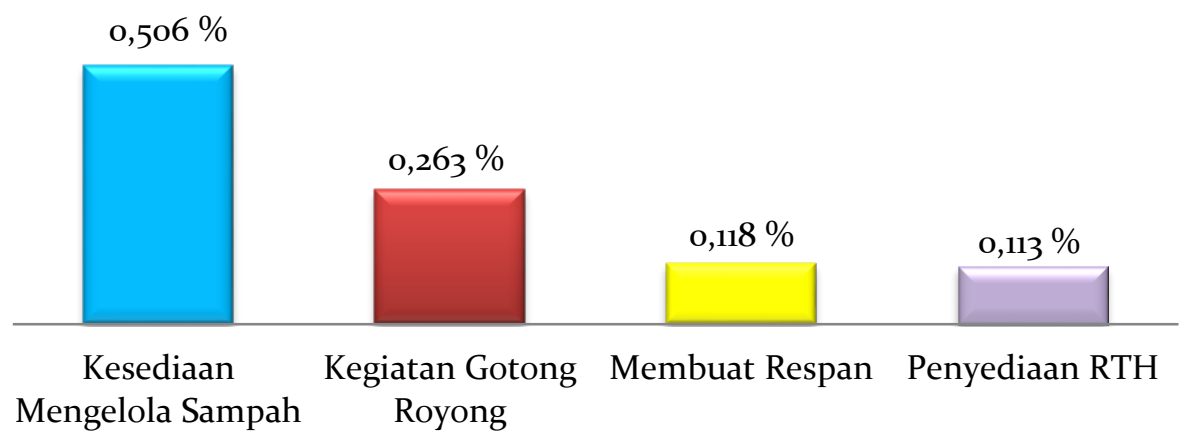

Gambar 4. Bobot Prioritas Berdasarkan sub kriteria Sosial

\subsubsection{Prioritas Sub-Faktor Ekonomi}

Berdasarkan hasil penilaian stakeholder pada sub faktor ekonomi, menghasilkan beberapa penilaian prioritas. Prioritas pertama pelatihan dan kewirausahaan dengan nilai kepentingan sebesar $0,346 \%$ atau $(34,6 \%)$, prioritas kedua pinjaman modal usaha dengan nilai kepentingan sebesar $0,335 \%$ atau $(33,5 \%)$ dan prioritas ketiga santunan bagi masyarakat miskin dengan nilai kepentingan $0,318 \%$ atau (31,8\%). Sedangkan Inconsistency responden dalam menilai adalah sebesar $0,01(<0,1 / 10 \%)$, nilai tersebut menunjukkan adanya kekonsistenan responden dalam menentukan prioritas kegiatan. Gambaran umum hasil penilaian disajikan pada Gambar 5.

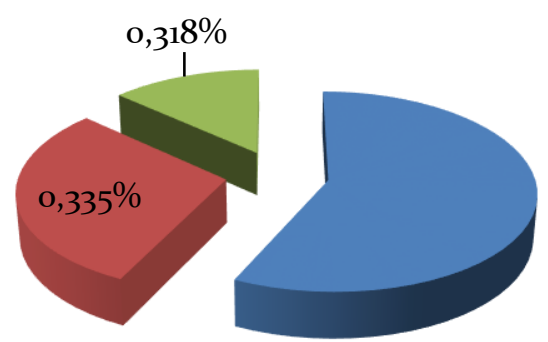

$0,346 \%$
- Pelatihan dan

Kewirausahaan

- Peminjaman Modal Usaha

- Santunan Bagi Masyarakat Miskin

Gambar 5. Bobot Prioritas Berdasarkan sub kriteria Ekonomi

\subsubsection{Prioritas Gabungan Seluruh Sub-Faktor 3 Pilar Pembangunan Berkelanjutan}

Penilaian gabungan seluruh sub faktor kegiatan bertujuan untuk menghasilkan nilai prioritas keseluruhan dengan jumlah 15 kegiatan dari masing-masing sub faktor berdasarkan 3 pilar pembangunan, dimana nilai bobot kepentingan yang paling tinggi mendekati angka $100 \%$ atau nilai diatas angka $50 \%$ direkomendasikan sebagai nilai prioritas untuk peningkatan kualitas lingkungan permukiman kumuh daerah 29 ilir. Hasil analisis terhadap susunan 15 kegiatan berdasarkan nilai tingkat kepentingan terdapat 8 (delapan) kegiatan prioritas. Prioritas pertama kesediaan mengelola sampah dengan nilai tingkat kepentingan sebesar $100 \%$, kedua sarana persampahan dengan nilai tingkat kepentingan sebesar 93,5\%, ketiga kegiatan gotong royong dengan nilai tingkat kepentingan sebesar 83,6\%, keempat perbaikan drainase lingkungan dengan nilai tingkat kepentingan sebesar $66,2 \%$, kelima kondisi sanitasi dengan nilai tingkat kepentingan sebesar 66,1\%, keenam pinjaman modal usaha dengan nilai tingkat kepentingan 63,0\%, ketujuh pelatihan dan kewirausahaan dengan nilai tingkat kepentingan sebesar $61 \%$ serta santunan bagi masyarakat miskin sebesar 57,9\%. Hasil penilaian gabungan secara rinci disajikan pada Gambar 6. 


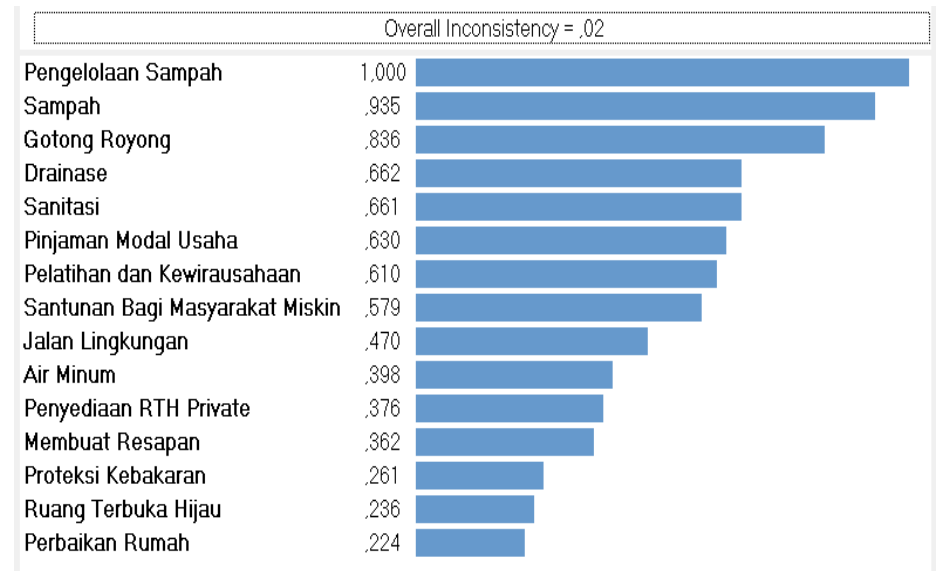

Gambar 6. Penilaian Gabungan Terhadap Seluruh Sub Kriteria

Kegiatan prioritas pada tabel tersebut diatas dari masing-masing 3 Pilar pembangunan, sebelumnya telah terbentuk bahwa aspek fisik lingkungan menjadi prioritas utama, namun setelah melihat hasil dari penilaian gabungan seluruh 15 kegiatan terbentuk menjadi 8 kegiatan prioritas, hal ini menunjukan prioritas kegiatan yang berbeda-berbeda, dimana kegiatan yang menjadi prioritas utama untuk perbaikan kualitas permukiman disetiap spot-spot kumuh daerah 29 Ilir berada pada faktor sosial yaitu mengelola persampahan rumah tangga sendiri dan kegiatan gotong royong.

\subsection{Analisis Kondisi 8 Kegiatan Prioritas Peningkatan Kualitas Permukiman Kumuh Daerah 29 Ilir Kota Palembang.}

\subsubsection{Karakteristik Pengelolaan Sampah Rumah Tangga}

Prioritas kegiatan dalam mengelola sampah rumah tangga dengan nilai kepentingannya sebesar 100 $\%$, hal ini menunjukkan pentingnya mengelola persampahan rumah tangga oleh masyarakat, kurangnya kepedulian warga untuk memelihara kebersihan lingkungan permukiman masih ada, terlihat sebagian masyarakat di lokasi prioritas daerah 29 Ilir dalam membuang sampah masih konvensional dengan memanfaatkan saluran/drainase, sungai dan halaman rumah sebagai tempat pembuangan sampah, semua terjadi karena sarana dan prasarana persampahan di lokasi prioritas dirasakan masih kurang. Berdasarkan penilaian dari 36 responden kesanggupan masyarakat untuk membuang sampah pada tempatnya sekitar 64 $\%$ bersedia dan kesanggupan masyarakat untuk memilah sampah sesuai jenisnya $36 \%$ bersedia. Hasil dari penilaian ini menunjukkan secara lisan mereka sanggup untuk melaksanakannya, kenyataan dilapangan masih banyak timbulan sampah baik di saluran, halaman rumah serta dilahan yang kosong.

\subsubsection{Karakteristik Kegiatan Gotong Royong}

Kegiatan gotong royong dengan nilai kepentingan sebesar 83,6 \%. Kegiatan ini menghasilkan penilaian kedua yang cukup tinggi, karena di lokasi prioritas daerah 29 Ilir kurangnya peranan masyarakat dalam memelihara prasarana lingkungan yang ada, seperti pembiaran aliran air yang tersumbat pada saluran, pembiaran adanya endapan lumpur pada badan saluran serta sebagian jaringan drainase banyak yang terputus dengan kondisi rusak sehingga menyebabkan genangan. Namun demikian pemerintah telah melakukan berbagai upaya salah satunya adanya program kegiatan gotong royong yang dilaksanakan setiap hari minggu dengan melibatkan perwakilan dari masing-masing rt. Kegiatan program tersebut diharapkan dapat merubah prilaku dan mengajak semua lapisan masyarakat untuk menjaga lingkungan permukiman. Keinginan untuk melaksanakan kegiatan gotong royong di lokasi prioritas, berdasarkan penilaian 36 responden $83 \%$ bersedia untuk melaksanakan kegiatan ini, Sedangkan $16 \%$ masyarakat menjawab belum mengetahui kegiatan program tersebut. 


\subsubsection{Karakteristik Sarana Persampahan}

Perbaikan sarana persampahan di lokasi prioritas daerah 29 Ilir sangat penting, terlihat dari nilai kepentingan para pakar terhadap perbaikan sarana persampahan sangat tinggi sebesar $93,5 \%$, penilaian ini berawal kondisi sarana persampahan di lokasi prioritas maupun seluruh wilayah daerah 29 Ilir belum terlayani seluruhnya. Berdasarkan penilaian 36 responden kondisi eksisting sarana persampahan di lokasi prioritas daerah 29 Ilir, meliputi ketersediaan tempat sampah, keterjangkauan sarana TPS, pelayanan pengangkutan sampah oleh dinas kebersihan, pemilahan sampah sesuai jenis, ketersediaan bank sampah, dan aktifitas pembuangan sampah rata-rata sebesar $60 \%$ belum terlayani seluruhnya dengan baik.

\subsubsection{Karakteristik Drainase Lingkungan}

Perbaikan kualitas lingkungan permukiman untuk menurunkan tingkat kekumuhan melalui perbaikan sistem drainase dengan tingkat kepentingan sebesar 66,2\%, perbaikan ini merupakan prioritas kegiatan yang cukup penting, karena kondisi drainase yang ada di wilayah permukiman daerah 29 Ilir terdiri dari 2 fungsi yaitu drainase utama merupakan saluran menuju ke sungai Musi dan drainase lingkungan merupakan saluran yang menghubungkan ke drainase utama, sebagian dalam kondisi fisiknya masih tanah dan belum seluruhnya terkoneksi dengan jaringan drainase utama, selain itu terjadinya pendangkalan oleh tanah yang bercampur sampah. Berdasarkan penilaian 36 responden kondisi drainase di lokasi prioritas mengalami kerusakan sebesar 36,5\%, ketersediaan jaringan drainase yang mengikuti jaringan jalan sebesar $16 \%$, terjadinya genangan sebesar $6 \%$ dan ketinggian air pada saat hujan tidak lebih dari $30 \mathrm{~cm}$ sebesar $8 \%$, ketersediaan lahan untuk penyerapan air di lokasi prioritas sebesar $32,4 \%$ dari luas wilayah kumuh yang ada di daerah 29 Ilir.

\subsubsection{Karakterstik Sanitasi Lingkungan}

Sistem saluran pembuangan limbah rumah tangga yang ada di lokasi prioritas daerah 29 Ilir seperti sumber dari mandi cuci kakus (MCK) pribadi maupun komunal merupakan salah satu permasalahan berkembangnya permukiman kumuh, sehingga para pakar menilai sebesar o,661 \% (66,1\%) permasalahan sanitasi di lokasi prioritas sangat penting dan harus segera diatasi. Sistem saluran air limbah seperti sumber dari jamban atau MCK dengan septictanknya yang ada di lokasi prioritas sangat jauh dari kelayakan, dimana sebagian rumah tangga belum seluruhnya terlayani dengan sistem air limbah yang baik, seperti tempat tinggal di sepanjang tepian Sungai Musi, sebagian besar masih menggunakan sungai sebagai media tempat untuk mandi, cuci dan buang air besar. Berdasarkan baseline data program peningkatan kualitas kawasan permukiman Kota Palembang terutama di daerah 29 Ilir, jumlah Jamban keluarga baik secara individu mapun komunal sebagian belum memenuhi persyaratan secara teknis yaitu sekitar $39 \%$ rumah tangga yang terhubung dengan septictank, sedangkan $61 \%$ rumah tangga belum memiliki kamar mandi yang memenuhi persyaratan sesuai teknis. Berdasarkan penilaian 36 responden rata-rata kondisi jamban, mck di lokasi prioritas yang terhubung ke septictank sebesar $23,9 \%$, serta yang tidak terhubung ke septiktank atau langsung ke saluran utama sebesar $39,2 \%$.

\subsubsection{Pinjaman Modal Usaha bagi Masyarakat Miskin}

Peningkatan kualitas lingkungan permukiman kumuh di lokasi prioritas melalui program pinjaman modal bagi masyarakat yang memiliki usaha yang tidak berkembang dan berkeinginan untuk meningkatkan usahanya sangat penting. Sehingga para pakar menilai $0,63 \%(63 \%)$ kepentingan untuk peningkatan kualitas lingkungan permukiman kumuh daerah 29 Ilir perlu dilakukan. Berdasarkan hasil penilaian dari 36 responden tingkat kepentingan terhadap program pinjmanan modal usaha melalui kegiatan keterampilan di lokasi prioritas sebesar $30 \%$ bersedia dari jumlah penduduk yang masih produktif. 


\subsubsection{Pelatihan dan kewirausahaan}

Pentingnya peningkatan kualitas lingkungan permukiman daerah 29 Ilir melalui pendekatan program kegiatan pelatihan dan kewirausahaan berdasarkan penilaian para pakar sebesar $61 \%$ sangat perlu dilakukan. Program tersebut diatas telah lama dilakukan oleh pemerintah Kota Palembang dengan melakukan pembinaan mengadakan pelatihan dan sosialisasi kepada masyarakat, melalui program pemberdayaan masyarakat untuk peningkatan kapasitas ekonomi bagi industri kecil dan menengah. Tujuan program tersebut agar kondisi ekonomi masyarakat bisa lebih baik. Berdasarkan penilain 36 responden sebesar $31 \%$ sampai dengan $40 \%$ kesediaan masyarakat untuk mengikuti program tersebut diatas.

\subsubsection{Santunan Bagi Masyarakat Miskin}

Kegiatan peningkatan kualitas lingkungan permukiman kumuh dengan memberikan bantuan santunan bagi masyarakat miskin dengan tingkat kepentingan terhadap kegiatan tersebut sebesar 57,9\% artinya kegiatan tersebut sangat penting dilakukan mengingat masih banyak masyarakat miskin atau berpenghasilan rendah di Kota Palembang yang belum berdaya terutama bagi penduduk yang masih produktif untuk bekerja dan juga masih orang tua yang lanjut usia maupun anak-anak yatim.

3.3. Lokasi Prioritas Peningkatan Kualitas Permukiman Kumuh Daerah 29 Ilir Kota Palembang. Penentuan lokasi prioritas penanganan lingkungan permukiman kumuh daerah 29 Ilir Kota Palembang, selain wawancara terhadap 36 responden juga melihat kondisi eksisting kualitas dan kuantitas infrastruktur dasar lingkungan. Hasil penilaian tersebut diatas disajikan pada Gambar 7.

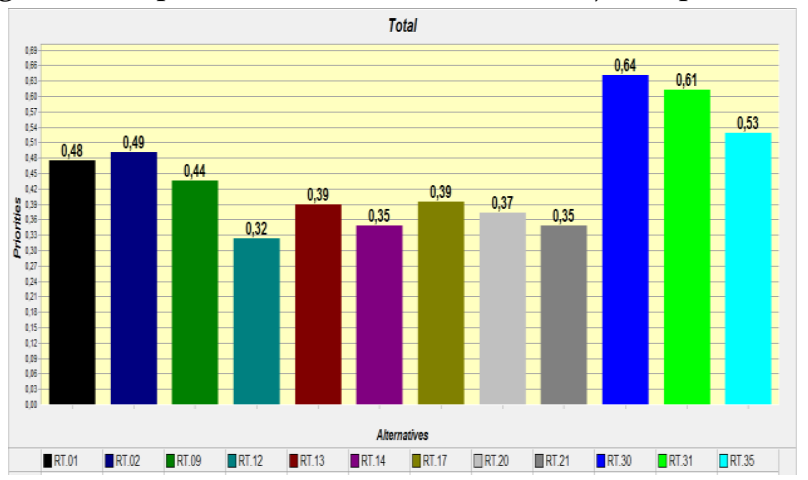

Gambar 7. Lokasi Prioritas

Prioritas lokasi kegiatan pada gambar tersebut di atas menunjukkan RT 30 dengan nilai tingkat kepentingan sebesar o,64\% (64\%) untuk peningkatan kualitas lingkungan permukiman merupakan prioritas pertama. Selain itu lokasi RT 30 merupakan wilayah kumuh dengan tingkat kebaikan lingkungan sebesar 25 $\%$ kategori buruk. Kondisi masyarakat di lokasi RT 30 memiliki $18 \mathrm{kk}$ masyarakat berpenghasilan rendah dari $42 \mathrm{kk}$ yang tersebar. Prioritas lokasi kedua berada di RT 31 dengan tingkat kepentingan sebesar o,61 (61\%), lokasi rt 31 merupakan wilayah kumuh dengan tingkat kebaikan $38 \%$ kategori sedang. Selain itu lokasi rt 31 memiliki $30 \mathrm{kk}$ masyarakat berpenghasilan rendah dari jumlah $45 \mathrm{kk}$ yang tersebar. Prioritas ketiga adalah lokasi RT 35 dengan tingkat kepentingan sebesar 53 \%. Lokasi RT 35 merupakan wilayah kumuh dengan tingkat kebaikan $22 \%$ kategori buruk. Selain itu, lokasi RT 35 memiliki 29 kk masyarakat berpenghasilan rendah dari jumlah 68 kk yang tersebar. Prioritas keempat adalah lokasi RT 02 merupakan lokasi prioritas dengan tingkat kepentingan sebesar $49 \%$. Lokasi RT 02 merupakan wilayah kumuh dengan tingkat kebaikan $22 \%$ kategori buruk. selain itu lokasi RT 02 memiliki 27 kk masyarakat berpenghasilan rendah dari jumlah $53 \mathrm{kk}$ yang tersebar dan juga lokasi ini sebagian tempat tinggalnya berada di tepian Sungai Musi. Prioritas kelima adalah lokasi RT o1 merupakan lokasi prioritas dengan tingkat kepentingan sebesar $48 \%$. Selain itu lokasi RT o1 memiliki $27 \mathrm{kk}$ masyarakat berpenghasilan rendah dari jumlah $73 \mathrm{kk}$ yang tersebar dan juga lokasi ini sebagian tempat tinggalnya berada di tepian Sungai Musi. Kelima lokasi prioritas yang tepilih 
merupakan daerah permukiman dengan kualitas sarana dan prasarannya kurang memadai. Secara umum kondisi kualitas lingkungan permukiman daerah 29 Ilir rata-rata 62\% sangat buruk. Gambaran umum sebaran lokasi yang diprioritaskan tersaji pada Gambar 8.

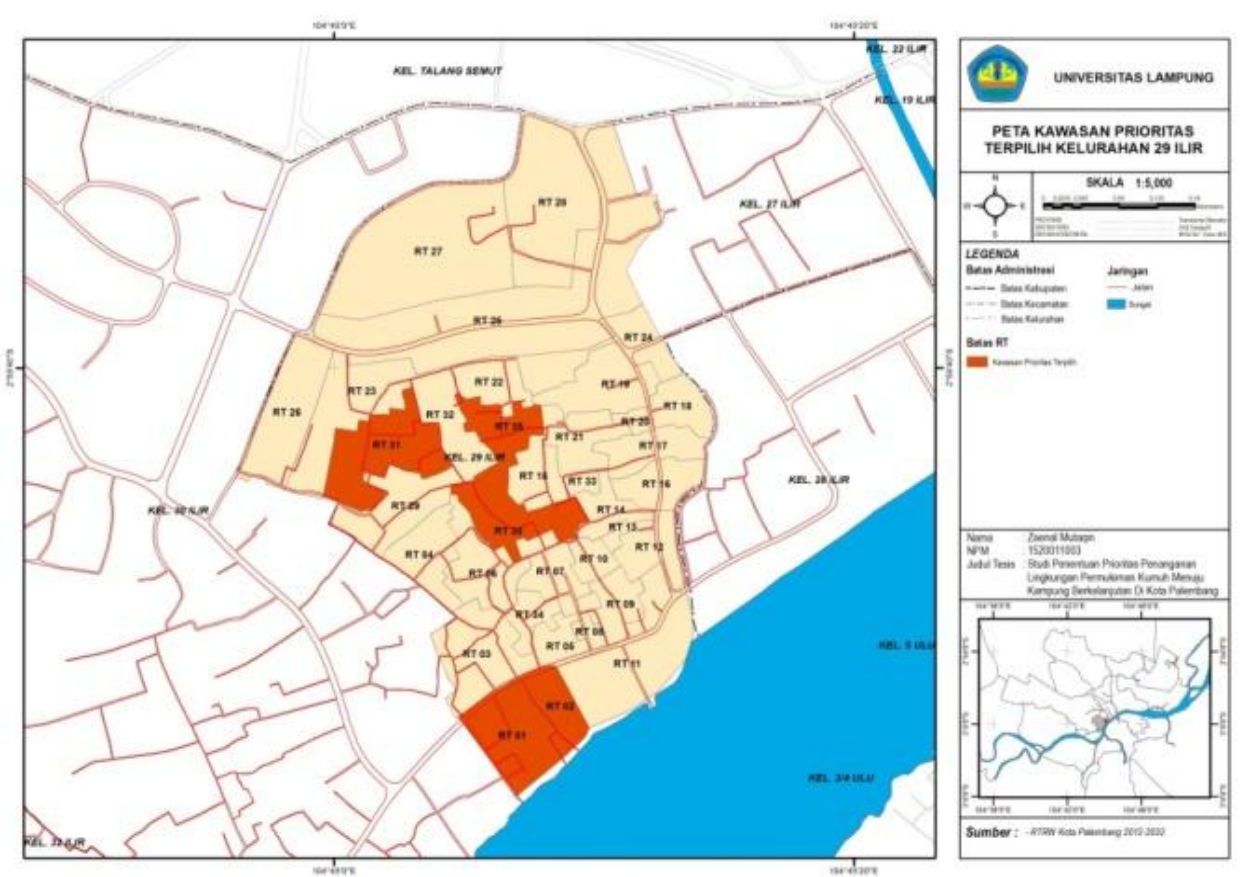

Gambar 8. Lima Lokasi Kawasan Prioritas

4. Kesimpulan

Berdasarkan hasil penelitian prioritas peningkatan kualitas terhadap permukiman kumuh yang berkelanjutan berdasarkan pengembangan dari 3 pilar pembangunan, menunjukkan bahwa untuk menurunkan tingkat kekumuhan adalah faktor peningkatan fisik lingkungan 46,7\%, prioritas kedua adalah faktor kegiatan sosial 31,2 \% dan faktor peningkatan ekonomi 22,1\%. Selanjutnya untuk penentuan prioritas kegiatan pada masing-masing faktor aspek 3 pilar pembangunan menunjukan prioritas yang berbeda, yaitu prioritas pertama ada pada faktor kegiatan sosial yaitu mengelola sampah rumah tangga $100 \%$ dan kegiatan gotong royong 83,6 \%. Prioritas kedua adalah pada faktor peningkatan fisik lingkungan yaitu perbaikan sarana persampahan 93,5\%, perbaikan drainase $66,2 \%$ dan perbaikan sanitasi $66,1 \%$, sedangkan prioritas ketiga adalah faktor ekonomi yaitu pinjaman modal usaha bagi masyarakat tidak mampu 63,0 \% dan pelatihan dan kewirausahaan 61,o \% serta santunan bagi masyarakat miskin sebesar $57,9 \%$.

Dari hasil tersebut dapat disimpulkan bahwa dalam menentukan prioritas peningkatan kualitas terhadap lingkungan permukiman kumuh, aspek sosial yang berkaitan dengan komitmen masyarakat untuk memelihara lingkungan dalam jangka panjang yang berkelanjutan lebih penting dibanding dengan aspek fisik dan aspek ekonomi. Selain itu hasil penelitian terhadap penentuan lokasi prioritas terkait peningkatan kualitas lingkungan permukiman kumuh daerah 29 Ilir dari 12 lokasi yang telah teridentifikasi untuk melaksanakan kegiatan 8 kegiatan prioritas tersebut di atas, diutamakan 5 lokasi prioritas yaitu RT 30, RT 31, RT 35, RT o2 dan RT o1.

Upaya peningkatan kualitas permukiman yang berkelanjutan disarankan:

a. Memperbanyak sarana persampahan terdiri dari TPS, tong sampah dan gerobak sampah dengan jumlah sarana persampahan belum memadai.

b. Perlu dilakukan kajian terhadap perencanaan Instalasi Pengelolaam Air Limbah (IPAL) di wilayah permukiman khususnya Kelurahan 29 Ilir Kota Palembang. 


\section{References}

Atmanti, H.D. 2008. Analytical Hierachy Process Sebagai Model Yang Luwes. Prosiding ISBN: 978-979-
97571-4-2.
Fakultas
Ekonomi
Undip.
Semarang.

http://eprints.undip.ac.id/33722/1/Analytical_hierarchy.pdf

Joga, N. 2013. Gerakan Kota Hijau. Jakarta. Gramedia Pustaka Utama.

Khoirunnisa, A., Haryono, D., dan Nugraha, A., 2013. Analisis Pendapatan dan Pengambilan Keputusan Dalam Menentukan Tanaman Sayuran Unggulan di Kecamatan Gisting Kabupaten Tanggamus. JIIA, Volume 1 No.2. Universitas Lampung.

Peraturan Menteri Pekerjaan Umum dan Perumahan Rakyat No.2/PRT/M/2016 Tentang Peningkatan Kualitas Terhadap Perumahan Kumuh dan Permukiman Kumuh.

Puslitbang, 2011. Pusat Penelitian dan Pengembangan Permukiman Kementerian Pekerjaan Umum

Saaty. 1990. How to make a decision: The Analytic Hierarchy Process. North-Holland. University of Pittsburgh, Pittsburgh, PA 1526o, USA. European Journal of Operational Research 48 (1990) 9269.

Surat Keputusan Walikota Palembang Nomor 488 Tahun 2014 Tentang Penetapan Lokasi Kawasan Permukiman

Syahri, 2013. Pembangunan Berkelanjutan Berbasis Green Moral. Bandung. Widya Aksara Press.

Undang-Undang No 1 Tahun 2011 Tentang Perumahan dan Kawasan Permukiman. 